\title{
Expression of a fungal ferulic acid esterase in alfalfa modifies cell wall digestibility
}

\author{
Ajay Badhan ${ }^{1}$, Long Jin ${ }^{1}$, Yuxi Wang ${ }^{1}$, Shuyou Han², Katarzyna Kowalczys ${ }^{3}$, Daniel CW Brown ${ }^{2,3}$, \\ Carlos Juarez Ayala ${ }^{2}$, Marysia Latoszek-Green², Brian Miki ${ }^{2}$, Adrian Tsang ${ }^{4}$ and Tim McAllister ${ }^{1 *}$
}

\begin{abstract}
Background: Alfalfa (Medicago sativa) is an important forage crop in North America owing to its high biomass production, perennial nature and ability to fix nitrogen. Feruloyl esterase (EC 3.1.1.73) hydrolyzes ester linkages in plant cell walls and has the potential to further improve alfalfa as biomass for biofuel production.

Results: In this study, faeB [GenBank:AJ309807] was synthesized at GenScript and sub-cloned into a novel pEACH vector containing different signaling peptides to target type B ferulic acid esterase (FAEB) proteins to the apoplast, chloroplast, endoplasmic reticulum and vacuole. Four constructs harboring faeB were transiently expressed in Nicotiana leaves, with FAEB accumulating at high levels in all target sites, except chloroplast. Stable transformed lines of alfalfa were subsequently obtained using Agrobacterium tumefaciens (LBA4404). Out of 136 transgenic plants regenerated, 18 independent lines exhibited FAEB activity. Subsequent in vitro digestibility and Fourier transformed infrared spectroscopy (FTIR) analysis of FAEB-expressing lines showed that they possessed modified cell wall morphology and composition with a reduction in ester linkages and elevated lignin content. Consequently, they were more recalcitrant to digestion by mixed ruminal microorganisms. Interestingly, delignification by alkaline peroxide treatment followed by exposure to a commercial cellulase mixture resulted in higher glucose release from transgenic lines as compared to the control line.
\end{abstract}

Conclusion: Modifying cell wall crosslinking has the potential to lower recalcitrance of holocellulose, but also exhibited unintended consequences on alfalfa cell wall digestibility due to elevated lignin content. The combination of efficient delignification treatment (alkaline peroxide) and transgenic esterase activity complement each other towards efficient and effective digestion of transgenic lines.

Keywords: Cell wall, Ferulic acid esterase, Animal nutrition, Lignin, Digestibility, Transgenic alfalfa

\section{Background}

Plant cell walls containing cellulose, hemicellulose, pectin and lignin are the most abundant organic resource on the planet [1]. Due to the limited availability of fossil carbon, as well as environmental concerns, comprehensive utilization of lignocellulosics for fuel and chemical production has currently raised much interest. Recalcitrance to scarification is a major limitation for conversion of lignocellulosic biomass to biofuels [2]. Plant cell walls represent a major source of nutritional energy for ruminants, but unfortunately with many types of forage, less than $50 \%$ of the cell wall fraction is readily digested

\footnotetext{
* Correspondence: tim.mcallister@agr.gc.ca

${ }^{1}$ Agriculture and Agri-Food Canada, Lethbridge Research Centre, 5403 1st Avenue South, Lethbridge, AB T1J 4B1, Canada

Full list of author information is available at the end of the article
}

and utilized by the ruminant host. Substantial benefits would be realized if a greater percentage of this potential energy was made available for fermentation through an increase in the digestibility of the cell wall fraction [3].

Plants have evolved effective mechanisms for resisting assault on their cell walls from the microbial and animal kingdoms. This intrinsic property underlies what has been termed 'recalcitrance', creating technical barriers to the cost effective transformation of lingo-cellulosic biomass into fermentable sugars. The natural factors believed to contribute to the recalcitrance of lignocellulosic feedstock to chemicals or enzymes include: 1 ) the epidermal tissue of the plant body, particularly the cuticle and epicuticular waxes; 2) the degree of lignification; 3) the structural heterogeneity and complexity of cell wall constituents such as microfibrils and matrix 
polymers; 4) the challenges for enzymes acting on an insoluble substrate; and 5) the inhibitors to subsequent fermentation that exist naturally in cell walls or are generated during the conversion process [4]. These chemical and structural features of biomass affect liquid penetration and/or enzyme accessibility and activity and, thus, conversion costs. These same constraints are equally relevant to the utilization of forage by ruminants.

Physical and chemical pretreatments have been developed to optimize the separation of lignin and cell wall polysaccharides from different feedstocks [5,6]. Plant fiber engineering is also seen as a route to improve feedstock characteristics and further reduce the energy and cost of refining biomass [7-9]. Several publications also describe the potential of modifying plant cell wall composition by altering the expression of endogenous enzymes involved in cell wall synthesis [10-12]. Similarly, cell wall composition, architecture and susceptibility to downstream processing can be improved through transgenic expression of exogenous carbohydrate-active enzymes (CAZymes) in planta. Expression of the type A ferulic acid esterase from Aspergillus niger (AnFaeA) in the grasses Lolium multiforum [13] and Festuca arundinacea [14] has been explored as a means of reducing cell wall crosslinking and thus increasing ruminal digestibility. The vast majority of AnFaeA transformed plant lines showed significant decreases in the cell wall content of ferulic acid and diferulate as compared to controls. Recently, Tsai et al. [15] reported altered intermolecular crosslinking within plant cell walls as a result of constitutive expression of a fungal glucuronoyl esterase in Arabidopsis. Likewise, improved rumen digestibility of forage could also increase their potential as raw materials for biofuel production. A recent study showed that simple modification of the cell wall in alfalfa dramatically increased its susceptibility to hydrolysis [16].

The aims of our study were to express the fungal (A. niger) feruloyl esterase $\mathrm{B}$ gene $(f a e B)$ in alfalfa by stable transformation, and to evaluate apoplast (A), chloroplast, endoplasmic reticulum (ER) and vacuole (V) targeted transgenic lines as a new feedstuff for ruminants as well as a biomass resource for cellulosic biofuel production. $f a e B$ was preferred over the feruloyl esterase A gene $(f a e A)$ considering its suitability for hydrolyzing ferulic acid esters in dicot cell walls (alfalfa), as dicots contain ferulated pectic polysaccharides as compared to grasses where ferulic acid is esterified to arabinoxylans. FAEB has been reported to be highly active against esterified pectin, while FAEA prefers esterified xylan.

\section{Results}

\section{Transgenic plants}

The number of plants regenerated from in vitro culture ranged from 33 (for the $f a e B$ targeted to endoplasmic reticulum) to 168 (for the $f a e B$ targeted to apoplast) using kanamycin resistance screening, with a total of 136 of these successfully rooted and established in the greenhouse. The efficiency of stable transformation, calculated as the percentage of explants (petioles) producing stable transgenic plants, varied with the construct. The recovery rate, based on PCR detection, of faeB-apoplast transgenic plants was found to be the highest at $54.2 \%$, while the recovery rate of $f a e B$-ER transgenic plants was the lowest at $8.3 \%$. Transformation efficiencies of alfalfa for the $f a e B$ construct targeted to the chloroplast was $20.8 \%$ and $30.0 \%$ for $f a e B$ targeted to the vacuole (Additional file 1).

\section{faeB expression in planta}

As a reporter gene for evaluating and optimizing the protocol for transient expression of the introduced gene in planta, we monitored transient expression of $\beta$-glucuronidase (GUS) in alfalfa leaves. To confirm the functionality of the construct and its ability to express in dicotyledonous plants in the targeted organelle, we used Western blot analysis of transiently transformed tobacco lines (Figure 1A) prior to stable transformation, and showed that the codon-optimized faeB genes were expressed in the apoplast, endoplasmic reticulum and vacuole with expression being highest in the endoplasmic reticulum. The gene did not express in the chloroplast. Transient GUS expression could be seen 5 days after infiltration with expression levels plateauing 10 days after infiltration (Figure 1B).

Of the 136 stably transformed lines based on PCR detection of the $f a e B$ gene and Southern blot (Additional file 2), 18 showed detectable levels of $f a e B$ activity (Figure 2A,B; data shown for representative lines $2 \mathrm{~V}$, ER28 and 3A covering one line from each genotype) using a microplate rapid screening assay [17]. Of the 18 faeB-expressing lines, 11 were targeted to apoplast, five targeted the vacuole and two targeted the endoplasmic reticulum. Transformed plants were clonally multiplied by taking cuttings of young growing shoots and rooted in a moist sand bed. Figure $2 \mathrm{~B}$ shows PCR confirmation of expression of the faeB transcript in transgenic lines used for further study. Representative transgenic lines were assessed using a whole-mount immunolocalization technique after Sauer et al. [18] to confirm recombinant protein localization in the target (endoplasmic reticulum, apoplast and vacuole) area and, as shown in Figure 2C, expression of genes was confirmed in the targeted plant cell compartment.

\section{In vitro digestion by mixed rumen microorganisms}

In vitro dry matter disappearance (IVDMD, \%) was lower $(P<0.05)$ for most of the transgenic lines as compared to the non-transformed clonal line after $6 \mathrm{~h}$ and $72 \mathrm{~h}$ of incubation with mixed ruminal fluid (Figure 3 ). This result suggests a possible negative effect of transgenic 


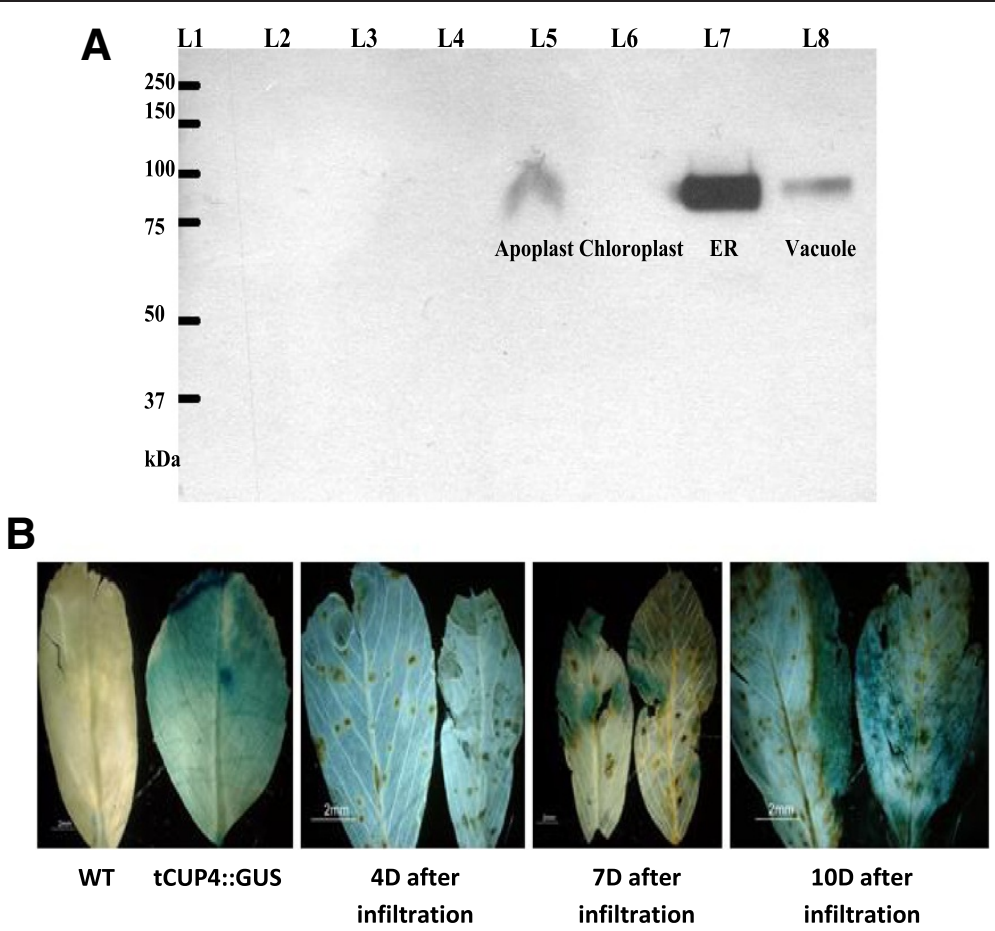

Figure 1 Gene expression analysis. (A) Western blot showing transient expression of faeB proteins in tobacco leaves. L1, protein ladder (catalogue number 161-0374; Bio-Rad, Hercules, CA, USA); L2, uninoculated leaf proteins; L3, proteins of tobacco leaves infected with LBA4404 (no construct); L4, proteins of tobacco leaves infected with agro harboring PEACH 5,103; L5, proteins of tobacco leaves infected with agro harboring faeB-apoplast; L6, proteins of tobacco leaves infected with agro harboring faeB-chloroplast; L7, proteins of tobacco leaves infected with agro harboring faeB-ER; and L8, proteins of tobacco leaves infected with agro harboring faeB-vacuole. (B) Transient expression of GUS in alfalfa leaves. tCUP:GUS was stably transformed into alfalfa plants (obtained from Dr Lining Tian, Agriculture and Agri-Food Canada London, ON, Canada), served as a positive control. ER, endoplasmic reticulum; GUS, $\beta$-glucuronidase.

esterase activity on digestibility of the plant cell wall, an unanticipated outcome. Total volatile fatty acid (VFA) concentrations arising from digestion (Additional file 3) were observed to be similar for the parental and transgenic lines. In vitro ammonia production was lower in transgenic as compared to non-transgenic lines (Additional file 4), suggesting that the transformation process also altered the fermentability of alfalfa protein.

\section{Cell wall analysis using Fourier transformed infrared spectroscopy (FTIR)}

To gain better insight into alterations in cell wall architecture, we further analyzed the cell walls of transgenic and non-transgenic alfalfa using Fourier transformed infrared spectroscopy (FTIR). FTIR spectra from cell walls of transgenic lines (spot (A) apoplast: average of spectrum from transgenic line 43A, 41A and $1 \mathrm{~A}$; spot (ER) endoplasmic reticulum: average of spectrum from transgenic line 28ER and 24ER; spot (V) vacuole: average of spectrum from transgenic line $61 \mathrm{~V}, 15 \mathrm{~V}$ and $2 \mathrm{~V}$ ) and the control $(\mathrm{C})$ line were used for data analysis. Principal component analysis (PCA) of spectra (Figure 4A), showed that vacuole and apoplast transgenic lines grouped separately from endoplasmic reticulum and control lines, suggesting compositional differences among lines. However, although the correlation map (Figure $4 \mathrm{~A}$ ) projected endoplasmic reticulum as being closely related to the control, the correlation matrix value of 0.9 for the control versus endoplasmic reticulum is indicative of significant compositional differences between these lines, a result confirmed by the correlation map of axis F1 versus F3 (Additional file 5). Loading factor score (F1) corresponding to PCA (Figure 4B) showed a characteristic peak of an ester bond at $1,750,1,735$ and $1,715 \mathrm{~cm}^{-1}$ indicating differences in the degree of esterification between the control and transgenic lines $[19,20]$. Furthermore, bands specific for lignin $\left(1,030,1,508,1,660\right.$ and 2,945 $\left.\mathrm{cm}^{-1}\right)$ also differed between the transgenic and control lines [19]. A broad peak between 3,200 to $3,400,2,915$ and $1,462 \mathrm{~cm}^{-1}$ was also indicative of elevated wax content in the transgenic as compared to the parental cell wall (Figure 4B) [20]. Elevated lignin content of transgenic lines was also evident from the peaks at $1,462 \mathrm{~cm}^{-1}$ (representing substituted $\mathrm{H}$ and HOC bending of aromatic skeletal vibration), $1,508 \mathrm{~cm}^{-1}$ (Aryl ring structure), 1,608 $\mathrm{cm}^{-1}$ (indicating existence of aromatic skeletal vibration, guaiacyl-syringyl type), $1,620 \mathrm{~cm}^{-1}$ (ring conjugated $\mathrm{C}=\mathrm{C}$ structure of coniferaldehyde) and 1,660 $\mathrm{cm}^{-1}$ (ring conjugated $\mathrm{C}=\mathrm{C}$ 


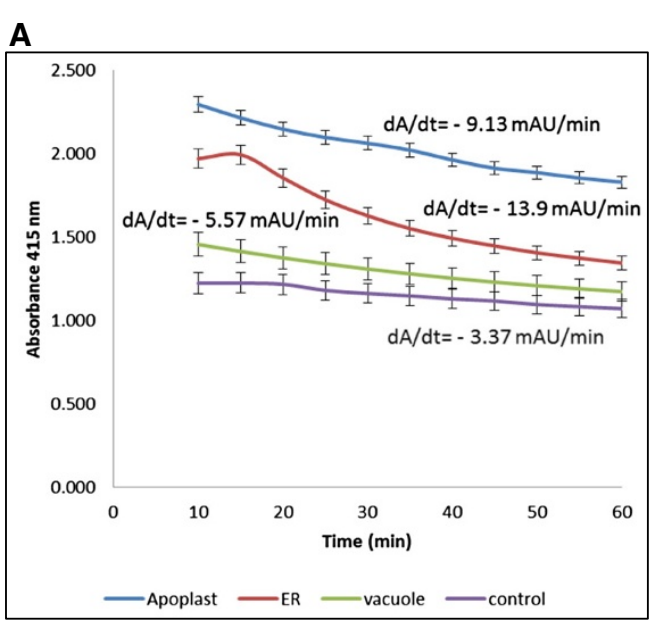

B

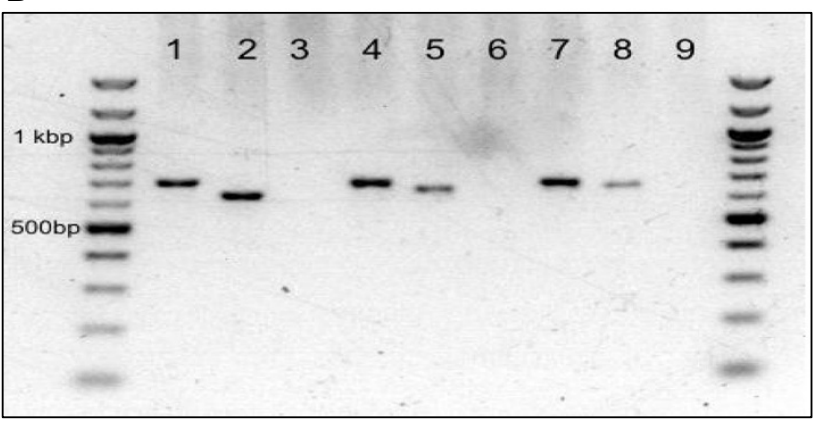

C

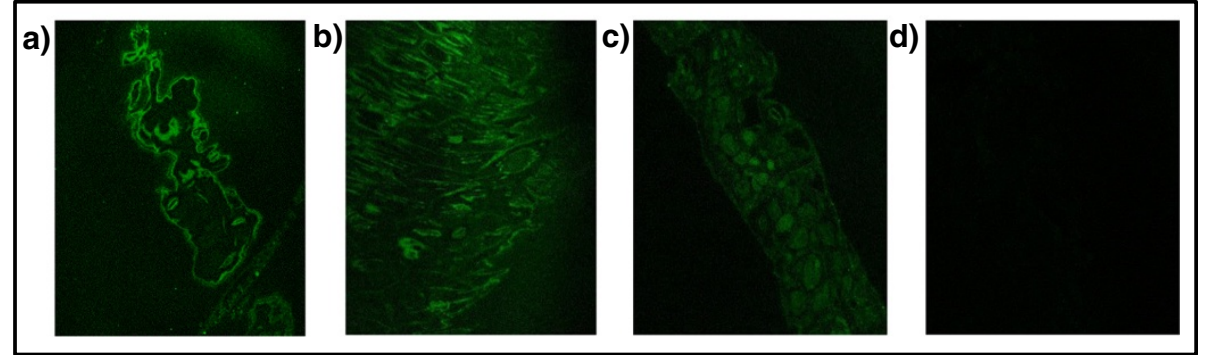

Figure 2 FAEB activity assay, PCR validation of $f a e B$ and immunocytochemical localization of FAEB. (A) FAEB activity as indicated by the change in absorbance over $60 \mathrm{~min}$ as a result of the hydrolysis of ethyl ferulate. Data represents three absorbance readings from the same extract from a single plant. Error bars indicate relative standard error. Apoplast (A), transgenic line 3A; control, wild type plant; endoplasmic reticulum (ER), transgenic line 28ER and vacuole (V), transgenic line $2 \mathrm{~V}$. (B) PCR validation of faeB gene in transgenic lines. Apoplast-expressing sample: lane 1, nptll (apoplast); lane 2, faeB-apoplast and lane 3, wild type negative control for faeB-apoplast. ER-expressing sample: lane 4, nptIl (ER); lane 5, faeB-ER and lane 6, wild type negative control for faeB-ER. Vacuole-expressing sample: lane 7, nptll (vacuole); lane 8, faeB-vacuole and lane 9, wild type negative control for faeB-vacuole. (C) Immunocytochemical localization to confirm recombinant protein expression in: (a) apoplast; (b) endoplasmic reticulum; (c) vacuole and (d) non-transgenic control in alfalfa leaves. A, apoplast; ER, endoplasmic reticulum; FAEB, type B ferulic acid esterase; $V$, vacuole.

structure of coniferyl alcohol; $\mathrm{C}=\mathrm{O}$ structure of coniferaldehyde) (Figure 4B) $[19,20]$.

To investigate the effect of these variations in cell wall composition on rumen digestibility, we further analyzed the residue remaining after $72 \mathrm{~h}$ of in vitro rumen digestion by mixed rumen microorganisms. Digital subtraction of FTIR spectrum of residual cell walls (control-transgenic lines) after $72 \mathrm{~h}$ of in vitro digestion showed that the residue from transgenic lines with esterase activity targeted to the endoplasmic reticulum exhibited significantly higher levels of hemicellulose $\left(1,100\right.$ to $\left.1,300 \mathrm{~cm}^{-1}\right)$ as compared to the control (Additional file 6A), whereas residue remaining when esterase was targeted to the apoplast had higher residual cellulose and hemicellulose (900 to $1,050 \mathrm{~cm}^{-1}$ ) content as compared to the control (Additional file 6B). To follow the progression of digestion 


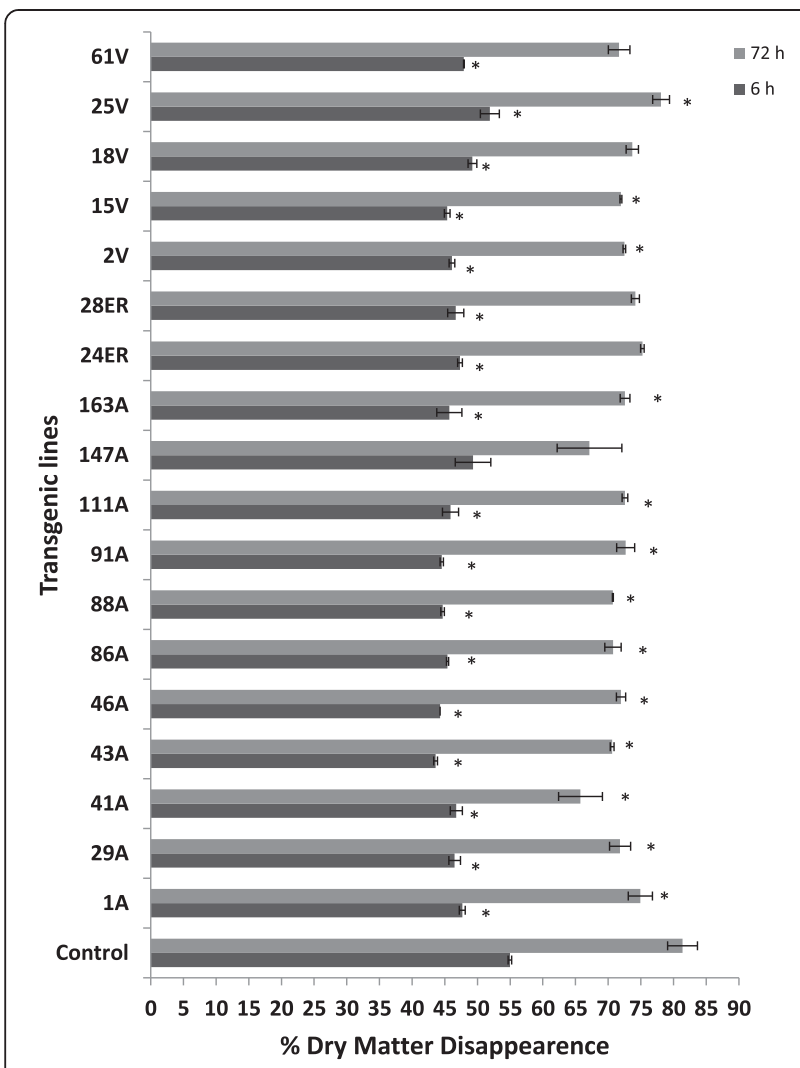

Figure 3 Effect of FAEB activity on in vitro dry matter disappearance (IVDMD) of control and various transgenic lines incubated with mixed ruminal fluid. Bars indicate standard error. *Differs to control at $P<0.05$. Repeated two times with triplicate samples per incubation. $A$, apoplast; $E R$, endoplasmic reticulum; FAEB, type $B$ ferulic acid esterase; IVDMD, in vitro dry matter disappearance; $V$, vacuole.

we further subtracted FTIR spectra of residual cell walls after $72 \mathrm{~h}$ of incubation from FTIR spectra of residue of cell walls after $6 \mathrm{~h}$ of incubation. Results indicated that the majority of the non-transgenic cell walls were digested between $6 \mathrm{~h}$ and $72 \mathrm{~h}$ (Additional file 7A). In contrast, the transgenic lines were observed to contain much higher levels of undigested cellulose and hemicellulose in the residue (Additional file 7B,C).

\section{Acetyl bromide solubilized lignin content, total sugar} content, total uronic acid and cell wall phenolic analysis Most transgenic lines (43A, 41A, 1A, 28ER, 24ER and $15 \mathrm{~V})$ exhibited higher $(P<0.05)$ levels of acetyl bromide soluble lignin as compared to non-transgenic lines (Figure 5A). Moreover, relative lignin content of residual cell walls after $72 \mathrm{~h}$ of digestion was also observed to be higher for transgenic lines (Figure 6A). Although the total sugar composition of sulfuric acid extracted cell wall fractions were observed to be similar among forage lines (Figure 5B and Additional file 8), the total sugar and uronic acid content were higher in residual cell walls of transgenic lines after $72 \mathrm{~h}$ of in vitro digestion as compared to the controls (Figures 6B,C). Transgenic lines with targeted esterase expression in the vacuole showed the highest release of phenolics (Figure 7A). Spectra showed characteristic peaks for ferulic and $p$ coumaric acid at 290 and $330 \mathrm{~nm}$ and 290 and $310 \mathrm{~nm}$, respectively. Elevated ferulic and $p$-coumaric acid in transgenic lines were evident from higher peaks at 290, 310 and $330 \mathrm{~nm}$ as compared to the control line (Figure 7B).

\section{Enzyme hydrolyzability assay}

As in vitro rumen digestion suggested a greater recalcitrance of transgenic lines it was proposed that cell wall carbohydrates in these lines could be made more accessible by delignification using alkaline hydrogen peroxide (AHP). To further explore this possibility, the AHP pretreated control and transgenic lines $(43 \mathrm{~A}, 41 \mathrm{~A}, 1 \mathrm{~A}, 28 \mathrm{ER}$, 24ER, $61 \mathrm{~V}, 15 \mathrm{~V}$ and $2 \mathrm{~V}$ ) were digested with a commercial mixed enzyme preparation (Accellerase 1500 containing endoglucanase: 2,200 to 2,800 carboxymethylcellulose (CMC) U/g and beta-glucosidase: 450 to $775 p$-nitrophenyl- $\beta$-D-glucopyranoside (pNPG) U/g). In agreement with incubations with mixed rumen microbes, glucose release from untreated control lines did not differ from untreated transgenic lines. In contrast, after pretreatment most transgenic lines released more glucose as compared to the control (Figure 8). Compared to the control, pretreated transgenic line 1A yielded 39\% more glucose, whereas transgenic lines $24 \mathrm{ER}$ and $15 \mathrm{~V}$ released 38\% and 29\% more glucose, respectively.

\section{Discussion}

Alfalfa is a valuable forage crop, primarily because of its high protein content and palatability for ruminants. However, the fiber fraction of alfalfa is often poorly digested and in fact can be even more lignified than grasses [21]. Acetyl group and linkages of uronic acid side chains to phenolic material have been identified as factors that limit the ruminal digestion of alfalfa [22]. Similarly, Giraldo et al. [23], Nsereko et al. [24] and Wang et al. [25] reported ester linkages between hemicellulose and lignin as the rate limiting factor in the ruminal digestion of plant cell walls. Hydrolyzing these linkages by chemical treatment with alkali is known to increase biodegradability and the nutritional value of low-quality feed. Reducing the level of crosslinking of cell wall carbohydrates is therefore a predictable way of improving forage quality through increases in the rate and possibly the extent of digestion [13].

In this study we developed alfalfa plants with transgenic ferulic acid esterase activity targeted to the apoplast, endoplasmic reticulum and vacuole. The targeting to these specific cellular organelles was based on 


\section{A}

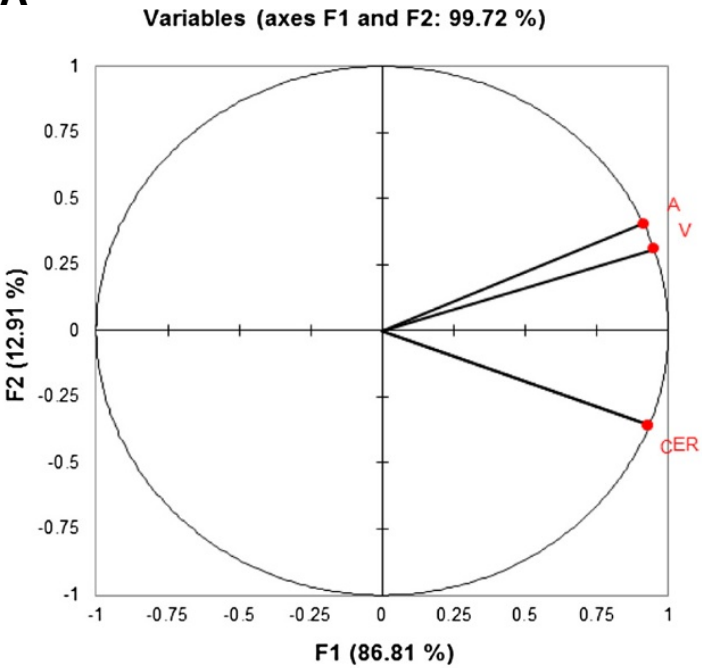

B

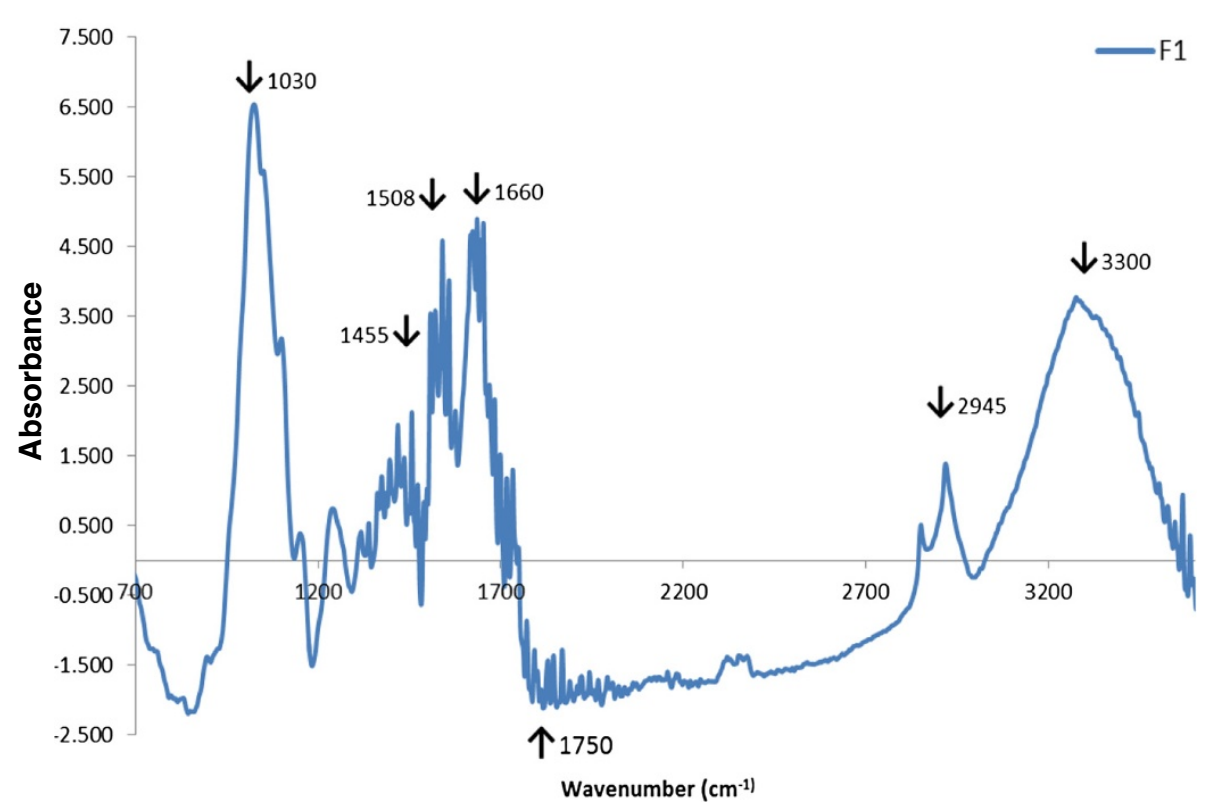

Figure 4 Fourier transformed infrared spectroscopy (FTIR) data analysis. (A) PCA of FTIR data. (B) Loading of factor score (F1) corresponding to PCA major spectral differences between transgenic and wild type lines. Apoplast (A), average spectrum of 43A, 41A and 1A; endoplasmic reticulum (ER), average spectrum of 24ER and 28ER; and vacuole $(\mathrm{V})$, average spectrum of $61 \mathrm{~V}, 15 \mathrm{~V}$ and $2 \mathrm{~V}$. C, control.

previous work using tobacco [26], which showed expression of recombinant proteins in these organs at a detectable level, particularly in the endoplasmic reticulum. The cell wall composition of transgenic lines assessed in this study $(43 \mathrm{~A}, 41 \mathrm{~A}, 1 \mathrm{~A}, 28 \mathrm{ER}, 24 \mathrm{ER}, 61 \mathrm{~V}, 15 \mathrm{~V}$ and $2 \mathrm{~V}$ ) was altered as a result of transgenic esterase activity to varying magnitudes. Interestingly, it seems that transgenic expression of ferulic acid esterase in alfalfa reduced its in vitro ruminal digestibility (Figure 3 ). This is likely attributed to the increase in lignin content of transgenic lines of alfalfa as indicated by FTIR spectrum analysis and wet chemistry. Likewise, the major monolignol constituents of lignin, that is the hydroxycinnamic acids, ferulic and $p$-coumaric acid, were found to be elevated in transgenic lines as compared to the control, likely a reflection of their higher lignin content. The increase in lignin content of transgenic lines observed in this study is in agreement with a recent report of elevated lignin levels in another dicot, Arabidopsis, expressing a fungal glucuronoyl esterase [15]. These results suggest that targeted expression of $f a e B$ in the endoplasmic reticulum/golgi apparatus (where ferulated arabinoxylan and pectin are formed prior to secretion to the cell wall) increased free ferulate content and the 

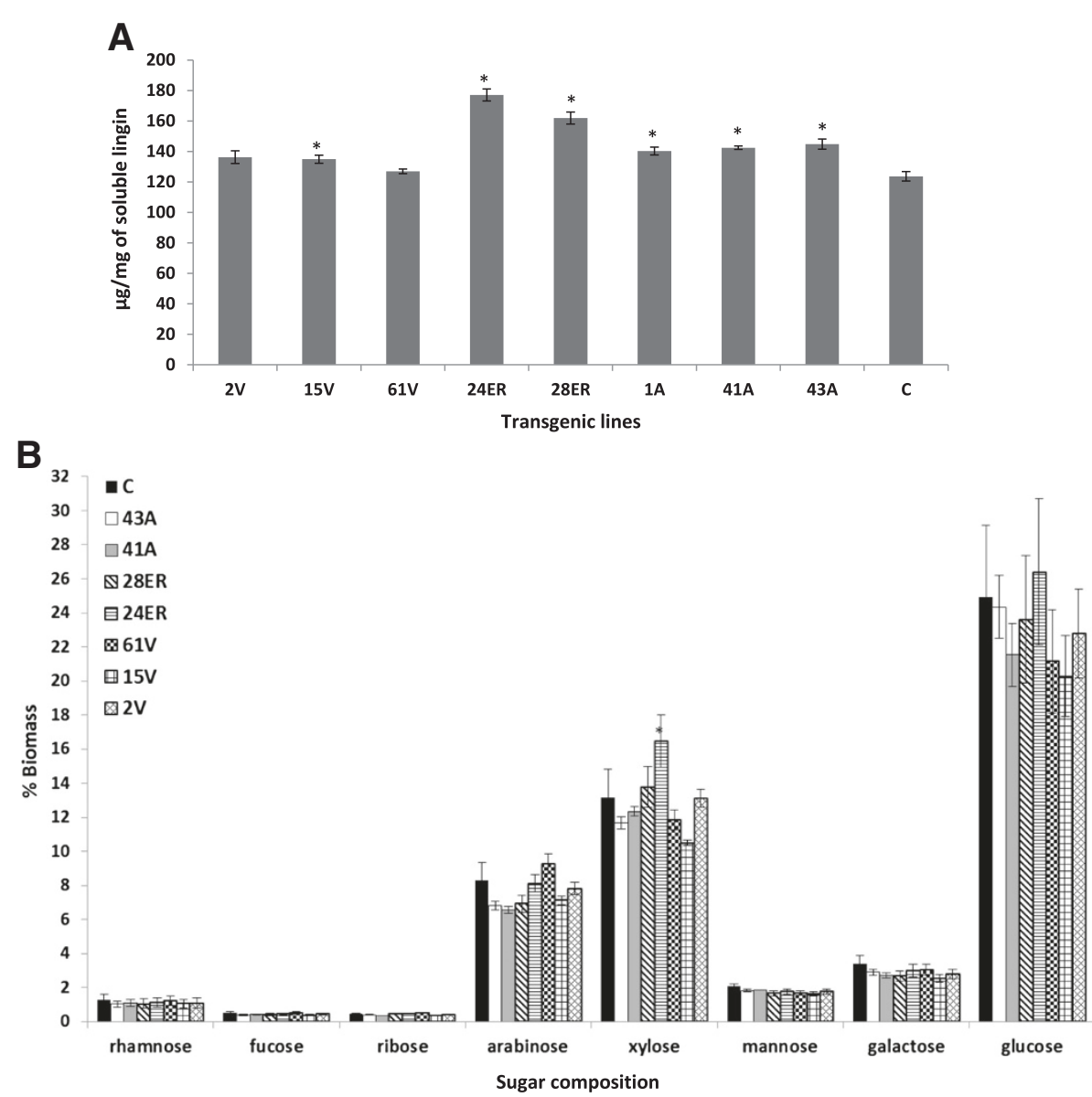

Figure 5 Lignin content and sugar compositional analysis. (A) Acetyl bromide soluble lignin content. Bars indicate standard error of mean $(n=3)$. * Differs to control at $P$ 0.05. (B) Sugar composition of control and transgenic alfalfa. Sugars were quantified as alditol acetate derivatives by GC-MS. Error bars indicate standard deviation $(n=3)$ of technical replicates from ground samples pooled from 50 to 60 whole plants per genotype. Alfalfa lines indicate expression of faeB in endoplasmic reticulum (ER), 24ER and 28ER; apoplast (A), 43A, 41A and 1A; and vacuole (V), $61 \mathrm{~V}, 15 \mathrm{~V}$ and $2 \mathrm{~V}$. A, apoplast; C, wild type control; ER, endoplasmic reticulum; GC-MS, gas chromatography-mass spectrometry; V, vacuole.

synthesis of lignin in transgenic lines. This hypothesis is supported by the finding that phenolic polymers are produced when levels of phenylpropanoid pathway intermediates or end products are increased [27]. Elevated wax content may also have contributed to the higher recalcitrance of transgenic lines. The visible phenotypic characteristics of recovered lines did not seem to be affected due to this change in lignin or wax content as transgenic plants were largely indistinguishable from controls, although expression of the introduced gene did impact the recovery of plants from cell culture. For dicots, strong negative correlations have been shown between initial lignin content and cellulose digestibility in alfalfa pretreated with dilute acid [16]. Phenolic components of the plant cell wall, especially $p$-coumaric acid, ferulic acid and $p$-hydroxybenzaldehyde have been reported to inhibit the growth of rumen microorganisms and cellulase activity $[28,29]$. Furthermore, it has been reported that lignin physically hinders the accessibility of enzymes to cellulose [30]. Moreover, soluble lignin-derived compounds may also cause enzyme inhibition [31]. The tendency of cellulase to bind irreversibly to lignaceous surfaces restricts conformational shifts in enzymes, which is crucial for the degradation of insoluble polysaccharides [32].

Notably then, delignification pretreatments such as AHP resulted in higher glucose release from transgenic as compared to the control line, a reflection of low recalcitrant core hemicellulose and cellulose constituents in transgenic lines. Previously, it has been reported that AHP not only effectively delignified cell walls but also improved overall hydrophilicity of the cell wall matrix, thereby increasing water and enzyme penetration [33]. Likewise, the relative improved digestibility of transgenic lines observed in this study after AHP treatment can be attributed to a combination of efficient delignification by AHP and transgenic esterase activity, leading to improved accessibility of cellulase and/or xylanase to low 

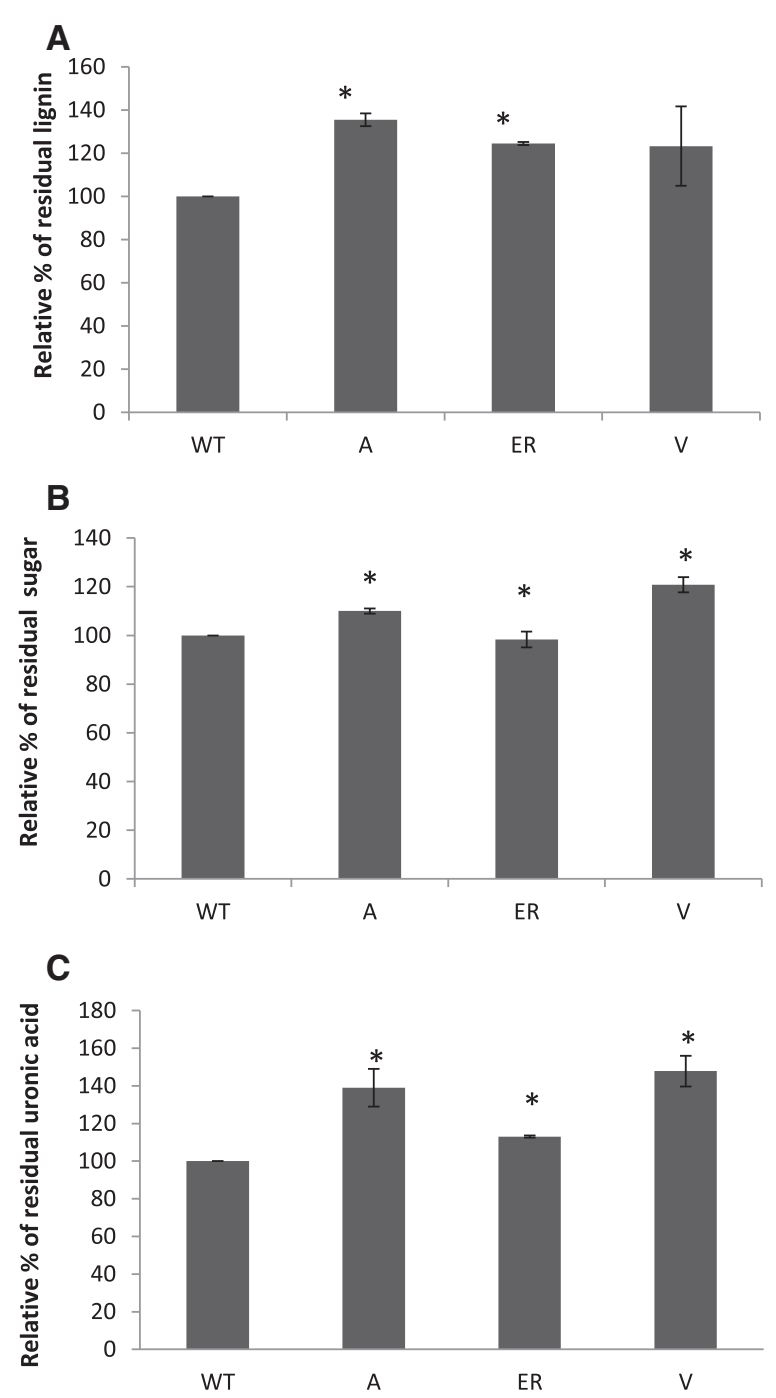

Figure 6 Residual lignin, total sugar and uronic acid content of cell walls after $72 \mathrm{~h}$ of in vitro digestion. Relative percentage of (A) residual lignin, (B) sugar and (C) uronic acid, which equal the percentage of lignin, sugar and uronic acid, respectively, remaining after $72 \mathrm{~h}$ of digestion relative to that of the control (control being $100 \%)$. Bars indicate standard error of mean $(n=3)$. *Differs to control at $P$ 0.05. Apoplast (A), fae $B$-apoplast (average of $43 \mathrm{~A}, 41 \mathrm{~A}$ and $1 \mathrm{~A}$ ); endoplasmic reticulum (ER), fae $B$-ER (average of 24ER and 28ER); and vacuole ( $)$, fae $B$-vacuole (average of $61 \mathrm{~V}, 15 \mathrm{~V}$ and $2 \mathrm{~V}$ ). A, apoplast; ER, endoplasmic reticulum; $V$, vacuole; WT, wild type.

recalcitrant core cell wall components. The approach adopted here therefore indicates the potential utility of modified cell wall crosslinking for improved and effective digestibility of plant cell walls for ethanol production and use by ruminants.

\section{Conclusions}

The results suggested reduced esterification, but increased lignin content in transgenic lines which possibly correlated to decreased rate of digestibility by ruminal microorganisms. Interestingly, alkaline peroxide pretreatment followed by commercial enzyme hydrolysis resulted in higher glucose release from transgenic lines than from wild type plants suggesting higher digestibility of the holocellulose content for transgenic lines after lignin removal. The present study demonstrates that expression of some genes involved in cell wall digestion can have unintended consequences on the cell wall digestibility of alfalfa.

\section{Methods}

\section{faeB gene}

Feruloyl esterase B (faeB) from A. niger is composed of 521 amino acids. Among them, 18 amino acids in the Nterminus function as a signal peptide that aides in the secretion of $f a e B$. To target the expression of $f a e B$ to specific plant organelles, we cleaved the $\mathrm{N}$-terminal signal peptide coding region, and replaced it with PR1b to target the proteins to the endoplasmic reticulum [34] and Rubisco leading the peptide to target expression to the chloroplast [26]. Endoplasmic reticulum retention signal KEDL [35] and vacuole retention signal CTPP (from R Menassa, Agriculture and Agri-Food Canada, London, ON, Canada) were fused immediately after the protein to target the protein to the endoplasmic reticulum and vacuole, respectively. The c-Myc tag was used for protein purification and StrepII was used for detection. The schematic maps of the four $f a e B$ constructs are shown in Additional file 9. The codon usage of the $f a e B$ gene was optimized based on alfalfa codon usage preference with $f a e B$ synthesized at GenScript (Township, NJ, USA). The sequences of synthetic faeB genes are shown in Additional file 10.

\section{Plasmid construction}

The transformation vector pPZP100 [36] was obtained from P Maliga (Rutgers University, New Brunswick, NJ, USA), and modified. In the pPZP100 vector, the CmR selectable marker gene was replaced with NPTII for selection of bacteria on kanamycin. The CmR gene generated instability in the vector, whereas it was stable with kanamycin (data not shown). In pEACH the nonmutated form of the NPTII gene [37] was inserted into the $\mathrm{CmR}$ gene, leaving the interrupted $\mathrm{CmR}$ gene sequence in the vector (Additional files 11 and 12). The MYB recognition sequence [38] allowed the excision of all sequences cloned into the multicloning site and acted as filler DNA to provide distance from the transfer DNA (T-DNA) borders [39], thereby minimizing interactions with elements at the insertion sites.

The plant selectable marker gene for kanamycin resistance was regulated by the enhanced tCUP4 promoter and $A R B C$ terminator with the terminator adjacent to the left T-DNA border. Any deletions occurring at the 

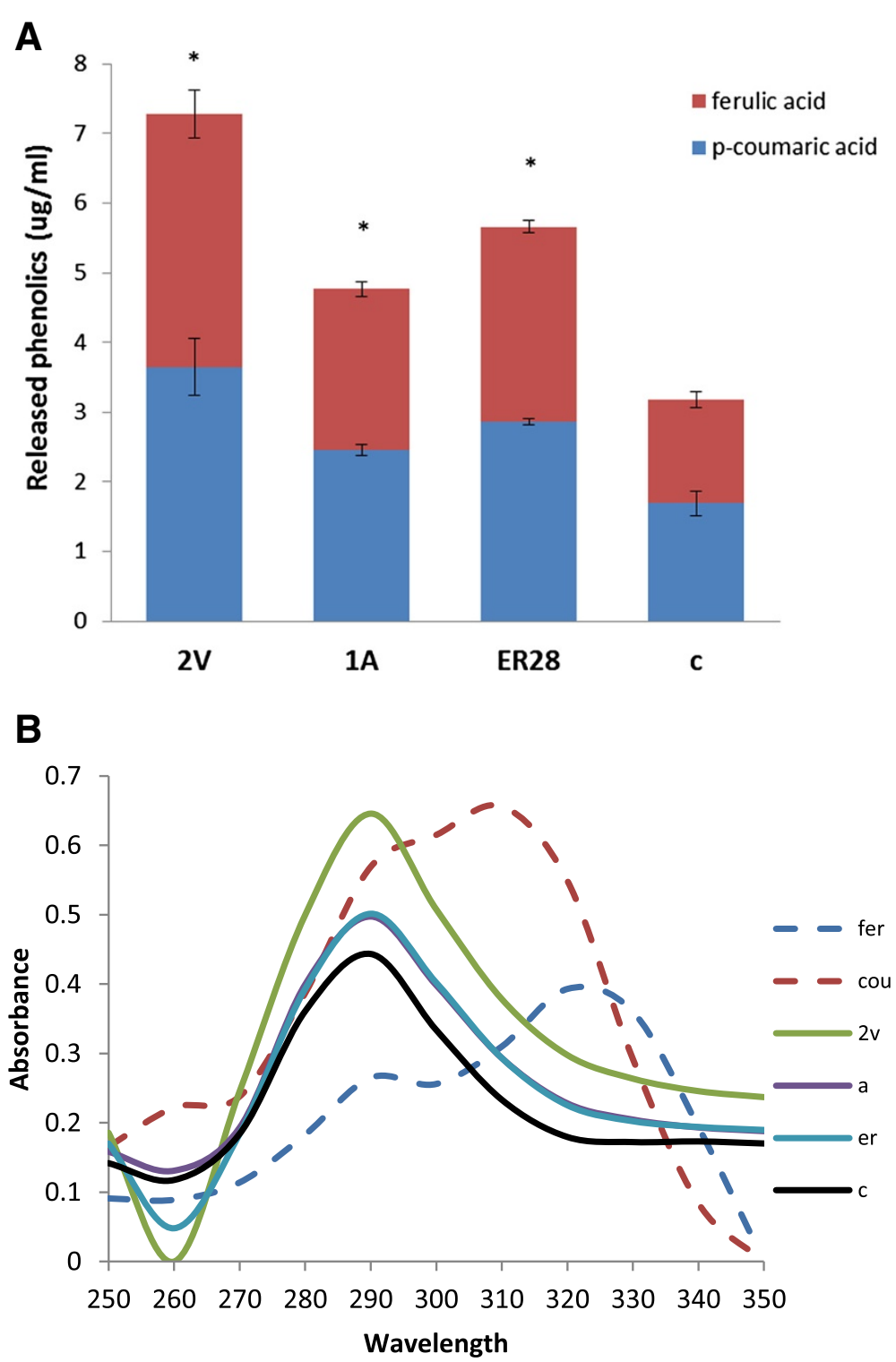

Figure 7 Cell wall extractable phenolics analysis. (A) Release of ferulic acid and p-coumaric acid as a result of extraction with $1 \mathrm{M} \mathrm{NaOH}$. (B) UV spectra of lignin fraction extracted with $1 \mathrm{M} \mathrm{NaOH}$ from control and three representative transgenic lines from endoplasmic reticulum (ER), apoplast (A), vacuole (2 V). and C, control.

left border would be selected against during plant tissue culture in the presence of kanamycin.

Genes regulated by the enhanced tCUP4 promoter and the PIN terminator were inserted in the same orientation as the selectable marker gene. The position of the enhanced tCUP4 promoter at the right border reduced the likelihood of promoter interactions with sequences within the adjacent insertion site. Enhanced tCUP4 has been shown to have no effect on the expression of adjacent genes, whereas the commonly used $35 \mathrm{~S}$ promoter and super-promoter have been shown to interact with elements at the insertion site over large distances [40].
The EcoR I-Hind III fragment from the pEACH vector was released from $\mathrm{pEACH} 5,103$ and subcloned into pUC18. In the resulting pUC18 vector, the synthetic $f a e B$ genes with protein signaling peptides were inserted between $B a m \mathrm{H}$ I and Xba I sites. Finally, the EcoR I-Hind III fragment from pUC18 vector was cloned back into pEACH 5,103, resulting in faeB-apoplast, faeB-chloroplast, $f a e B$-ER and $f a e B-$ vacuole constructs, respectively. All inserts were sequenced to confirm identity to original sequences.

The schematic map of the four $f a e B$ constructs is shown in Additional file 9. 


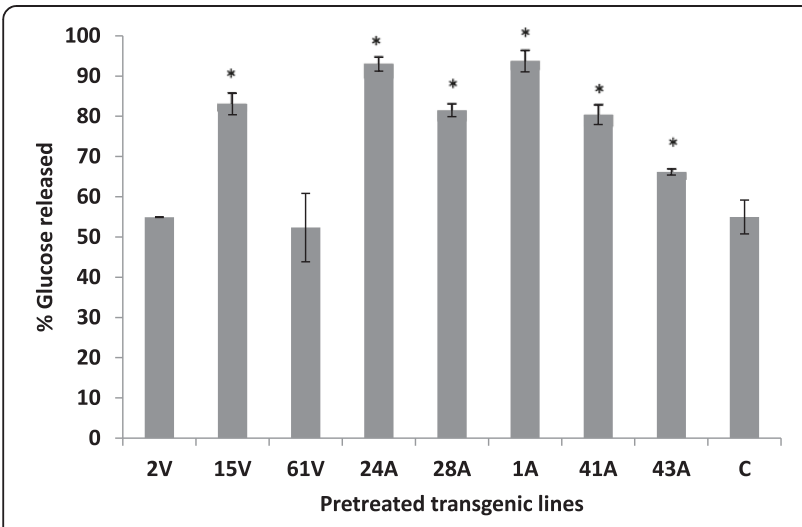

Figure 8 Effect of delignification by alkaline peroxide pretreatment on glucose released from control and transgenic lines as a result of hydrolysis with commercial enzyme preparations (Accellerase 1500). Bars indicate standard error of mean $(n=8)$. * Differs to control at $P<0.05$. Alfalfa lines indicate expression of faeB in endoplasmic reticulum (ER), 24ER and 28ER; apoplast (A), 43A, 41A and $1 \mathrm{~A}$; and vacuole $(\mathrm{V}), 61 \mathrm{~V}, 15 \mathrm{~V}$ and $2 \mathrm{~V}$. $\mathrm{A}$, apoplast; C, wild type control; ER, endoplasmic reticulum; $V$, vacuole.

\section{fae $B$ transient expression in tobacco}

The four $f a e B$ expression constructs were integrated into Agrobacterium tumefaciens strain LBA4401 using electroporation and were transiently expressed in 5- to 6-weekold Nicotiana benthamiana as described by Joensuu et al. [41]. Total proteins were extracted from tobacco leaves infected with LBA4404 Agrobacterium, LBA4404 transformed with pEACH 5,103 (GUS-intron), faeB-apoplast, faeB-chloroplast, faeB-ER and faeB-vacuole vectors, respectively, and $25 \mu \mathrm{g}$ of each protein was run on SDSPAGE gel. Expressed $f a e B$ proteins were detected using the primary antibody anti-c-Myc (GenScript; 1,500 x) and the secondary antibody, goat anti-mouse immunoglobulin G (IgG) with horseradish peroxidase (Bio-Rad; 3,000 ×).

\section{Tissue culture and plant transformation}

Donor plants of alfalfa (Medicago sativa L.) genotype N.4.4.2 were propagated in vitro by subculturing individual nodes in $10 \mathrm{~cm}$ magenta containers containing $0.5 \times$ Murashige and Skoog medium (MSO) [42]. The standard conditions for maintaining the cultures in a growth chamber were $25^{\circ} \mathrm{C}$ (day/night) with a photoperiod of $16 \mathrm{~h}$ at approximately 3,500 lux.

For alfalfa tissue culture and transformation, the procedures were performed as outlined in Han et al. [43]. Briefly, the petioles were cut to $1 \mathrm{~cm}$ lengths and precultured on $\mathrm{SH} 2 \mathrm{~K}$ medium [44] for $48 \mathrm{~h}$ at $25^{\circ} \mathrm{C}$ with a photoperiod of $16 \mathrm{~h}$. After pre-culture, explants were immersed (shortly for 2 to 5 seconds) in a suspension of Agrobacterium cells cultured overnight $\left(\mathrm{OD}_{600}=0.6\right.$ to 0.8). After immersion, petioles were blotted onto filter paper and placed on $\mathrm{SH} 2 \mathrm{~K}$ medium and co-cultivated for 5 days in the dark. The petioles were then transferred to the medium used for co-cultivation containing $300 \mathrm{mg} / \mathrm{l}$ timentin, and incubated for 2 weeks. When callus formation was observed, calli were transferred onto SH2K medium containing $50 \mathrm{mg} / \mathrm{l}$ kanamycin and $300 \mathrm{mg} / \mathrm{l}$ timentin. Calli surviving 1 week on this selection medium were moved to medium containing $75 \mathrm{mg} / \mathrm{l} \mathrm{kanamycin}$ and $300 \mathrm{mg} / \mathrm{l}$ timentin, and incubated for another 2 weeks. The calli were then transferred to the embryo induction medium BOi2Y $[45,46]$ containing $300 \mathrm{mg} / \mathrm{l}$ timentin and $75 \mathrm{mg} / \mathrm{l} \mathrm{kanamycin}$, and incubated for 3 weeks in the light with a photoperiod of 16:8. Green elongated mature embryos with well-formed cotyledons were collected and transferred to $0.5 \times$ MSO medium with $300 \mathrm{mg} / \mathrm{l}$ timentin and $75 \mathrm{mg} / \mathrm{l}$ kanamycin for 2 to 3 weeks. Germinated embryos were transferred to MSO containing $300 \mathrm{mg} / \mathrm{l}$ timentin and $25 \mathrm{mg} / \mathrm{l}$ kanamycin in magenta boxes. Wellestablished plants were transferred to soil. As a negative control, non-transformed explants were placed in SH2K medium with kanamycin $(75 \mathrm{mg} / \mathrm{l})$ to ensure effective selection of transformants (Additional file 13).

\section{Plant material}

The control (non-transformed) and regenerated transgenic lines were multiplied in a greenhouse using cuttings of actively growing young shoots rooted in a moist sand bed, transferred to a soilless potting mixture (Pro-Mix, Premier Tech Horticulture, Rivière- duLoup, QC, Canada) and grown in $200 \mathrm{~cm}$ plastic pots under seasonal greenhouse conditions, with daily watering and weekly fertilization (20 N:20P:20 K). Actively growing shoots were collected from all lines at the pre-bud vegetative stage, freeze-dried and stored at $-20^{\circ} \mathrm{C}$.

\section{Validation by PCR and southern hybridization}

Genomic DNA was extracted from leaves of putative transformed and non-transformed alfalfa plants using a commercially available kit (REDExtract-N-Amp ${ }^{\text {тм }}$ Plant PCR Kit; Sigma-Aldrich, St Louis, MO, USA). The integration of transgenes into the alfalfa genome was confirmed by PCR with primers targeting the nptII and faeB genes. Additionally, a common tCUP4 promoter forward primer was used in combination with transgene specific reverse primers for $f a e B$-apoplast, faeB-chloroplast, faeBER and faeB-vacuole. For amplification of the nptII gene, a 699 bp fragment was amplified using the forward primer (5'GAGGCTATTCGGCTATGACTG3') and the reverse primer (5'ATCGGGAGCGGCGATACCGTA3'). The primers for amplification of $f a e B$ gene fragments of four constructs were as follows. For the faeB-apoplast construct, the forward primer was (5'ACGGTGGAGAGGCTGATA3') and the reverse primer was (5'GGATGACTCCAAAGATCCTC3'), generating a product of $652 \mathrm{bp}$. For the faeB-chloroplast construct, the forward primer was (5'CTGCTGCTGTTGCAACAAGG3') 
and the reverse primer was (5'GGAAAGCACCCCATGA3'), generating a product of $765 \mathrm{bp}$. For the faeB-vacuole construct, the forward primer was (5'ACGGTGGAGAGGCTGATA3') and the reverse primer was (5'CCTTACATAGTAACAAGCAAACCG3'), generating a product of $695 \mathrm{bp}$. For the faeB-ER construct, the forward primer was (5'ACGGTGGAGGCTGATA3') and the reverse primer was (5'GGATCCTTAAAGTTCATCTT3'), with PCR product size of $680 \mathrm{bp}$. The conditions of PCR were set as follows: $94^{\circ} \mathrm{C}, 5 \mathrm{~min} ; 30$ cycles at $94^{\circ} \mathrm{C}, 30 \mathrm{sec} ; 58^{\circ} \mathrm{C}, 30 \mathrm{sec} ; 72^{\circ} \mathrm{C}, 30 \mathrm{sec}$; and a final extension at $72^{\circ} \mathrm{C}, 5 \mathrm{~min}$. The primers used for amplification of the tCUP4 promoter and transgene specific reverse primers for $f a e B$-apoplast, faeB-chloroplast, $f a e B$-ER and faeB-vacuole were used. The forward primer flanking tCUP4 promoter was (5'CGGCAGAATTTCCCTATATATATTTTTAATTCCCAAA3') and the transgene specific reverse primers were as follows: faeB-apoplast reverse primer was (5'GGATGACTCCAAAGATCCTC3'), the size of PCR product was $1,809 \mathrm{bp}$; faeB- chloroplast reverse primer was (5'GGAAAGCACCCCATGA3'), generating a PCR product of $956 \mathrm{bp}$; faeB-ER reverse primer was (5'GGATCCTTAAAGTTCATCTT3'), the size of PCR product was $1,842 \mathrm{bp}$; and $f a e B$-vacuole reverse primer was (5'CCTTACATAGTAACAAGCAAACCG3'), generating a PCR product of 1,695 bp. PCR conditions were as follows: $94^{\circ} \mathrm{C}, 5 \mathrm{~min} ; 35$ cycles at $94^{\circ} \mathrm{C}, 30 \mathrm{sec} ; 55^{\circ} \mathrm{C}, 30 \mathrm{sec}$; $72^{\circ} \mathrm{C}, 1 \mathrm{~min} 45 \mathrm{sec}$; and the final extension at $72^{\circ} \mathrm{C}, 5 \mathrm{~min}$.

For Southern analysis, total genomic DNA was isolated from selected transgenic and control plants, then digested overnight with HindIII (New England Biolabs, Ipswich, MA, USA), with $10 \mu \mathrm{g}$ of digested DNA being separated by agarose electrophoresis. DNA was transferred onto a Hybond-N membrane (GE Healthcare Life Sciences, Mississauga, ON, Canada) by capillary blotting. DNA was fixed to the membrane by UV crosslinking and probed with digoxigenin-labeled $f a e B$ prepared by PCR of plasmid DNA.

\section{In situ immunolocalization}

In situ immunolocalization of transgenic protein in the different organelles was performed on young alfalfa leaf tissue from transgenic and control plants, according to the protocol described by Sauer et al. [18]. A 1:1,000 dilution of the $0.5 \mathrm{mg} / \mathrm{ml}$ stock of c-Myc anti-mouse antibody was used as the primary antibody and a 1:30 dilution of donkey anti-mouse IgG antibody stock (Molecular Probes, catalogue number A21202) labeled with Alexa Fluor 488 (Life Technologies, Carlsbad, CA, USA) was used as the secondary antibody.

\section{Feruloyl esterase activity screening}

Enzyme was extracted by grinding $3 \mathrm{~g}$ of stem and leaf tissue in liquid nitrogen, followed by suspension in
$10 \mathrm{ml}$ of extraction buffer (0.1\% PBS Tween-20, 2\% PVPP, $1 \mathrm{mM}$ EDTA, $1 \mathrm{mM}$ PMSF, $1 \mu \mathrm{g}$ leupeptin, $100 \mathrm{mM}$ ascorbic acid, $\mathrm{pH}$ 7.4). Crude protein extract was recovered by centrifugation and concentrated using centrifugal filters (Centriprep YM-10; EMD Millipore, Billerica, MA, USA). The concentrate was resuspended in $3 \mathrm{ml}$ of $2.5 \mathrm{mM} 3-$ (N-morpholino)propanesulfonic acid (MOPS) buffer ( $\mathrm{pH}$ 7.2) and reisolated by centrifugation into a final volume of less than $1 \mathrm{ml}$. For preliminary assessment of feruloyl esterase activity in transgenic lines, enzyme was qualitatively estimated using a microplate screening assay [17] by measuring the hydrolysis of ethyl ferulate $(50 \mathrm{mM}$ ethyl ferulate, $5 \mathrm{mM}$ of $p$-nitrophenol in isopropanol, diluted in nine volumes of $2.5 \mathrm{mM}$ MOPS, $\mathrm{pH}$ 7.2). To test the samples, $10 \mathrm{mg}$ (in triplicate) of concentrated plant protein extracts in $20 \mu \mathrm{l}$ of $2.5 \mathrm{mM}$ MOPS ( $\mathrm{pH}$ 7.2) were placed in each microplate well, and $100 \mu$ of substrate was added immediately before readings. Decrease in absorbance at $415 \mathrm{~nm}$ at $30^{\circ} \mathrm{C}$ was recorded (from triplicates) every $5 \mathrm{~min}$ for $1 \mathrm{~h}$. Relative enzyme activity was determined by linear regression of the decrease in absorbance versus time and slope of the regression equation (Figure 2A).

\section{In vitro ruminal incubation}

In vitro ruminal incubations were performed in $125 \mathrm{ml}$ serum vials fitted with rubber stoppers. Whole alfalfa plants were ground to pass a $1.0 \mathrm{~mm}$ screen, and weighed into filter bags (F57; Ankom, Macedon, NY, USA; $0.5 \mathrm{~g}$ per bag) and loaded into vials prior to addition of ruminal inoculum. Six cows with permanent rumen cannula, fed an alfalfa hay diet were used as rumen fluid donors. Cattle used in this study were cared for in accordance with standards of the Canadian Council on Animal Care (CCAC, 1993). Rumen fluid was collected $2 \mathrm{~h}$ after feeding from five different locations in the rumen-reticulum and strained through four layers of cheese cloth. Equal amounts of rumen fluid from each cow were combined, mixed with a mineral buffer [47] in a ratio of 1:2 to serve as inoculum. Incubations were initiated by dispensing $20 \mathrm{ml}$ of inoculum under a stream of $\mathrm{CO}_{2}$ into vials containing each substrate in F57 filter bags. The vials were immediately sealed and affixed to a rotary shaking platform $(125 \mathrm{rpm})$ in a $39^{\circ} \mathrm{C}$ incubator (model 39419-1; Forma Scientific, Marietta, OH, USA). Triplicate vials for each sample and blank were retrieved from the incubator after $6 \mathrm{~h}$ and $72 \mathrm{~h}$ of incubation and processed for determination of VFAs, ammonia and IVDMD as previously described [48].

Residue remaining in the filter bag was rinsed thrice with phosphate buffer $(\mathrm{pH} 7.0)$, dried at $55^{\circ} \mathrm{C}$ and weighed to estimate the IVDMD. Two subsamples of the liquid culture were taken $(1.5 \mathrm{ml}$ each) from each vial immediately after retrieval of the filter bags. One sample 
was transferred to a $2 \mathrm{ml}$ microcentrifuge tube containing $126 \mu \mathrm{l}$ of trichloroacetic acid (TCA; 65\% w/v) and centrifuged at $14,000 \times g$ for $10 \mathrm{~min}$ to precipitate particulate. The supernatant was transferred into $2.0 \mathrm{ml}$ microcentrifuge tubes and stored at $-20^{\circ} \mathrm{C}$ until analysis for ammonia by the phenyl-hypochlorite method [49]. Another sample was mixed with $0.3 \mathrm{ml}$ of metaphosphoric acid $(25 \% \mathrm{w} / \mathrm{v})$, centrifuged at $14,000 \times \mathrm{g}$ for $10 \mathrm{~min}$ and the supernatant was analyzed for VFA as described by Wang et al. [50].

\section{Attenuated total reflectance Fourier transform infrared spectroscopy (ATR-FTIR)}

Ground samples and residues from in vitro digestion of transgenic (43A, 41A, 1A, 28ER, 24ER, $61 \mathrm{~V}, 15 \mathrm{~V}$ and $2 \mathrm{~V}$ ) and control plants were subjected to FTIR spectroscopy using ALPHA FT-IR spectrometer (Bruker Optics, Ettlingen, Germany) equipped with a platinum diamond attenuated total reflectance (ATR) attachment. Spectra were collected over 4,000 to $600 \mathrm{~cm}^{-1}$ with resolution of $4 \mathrm{~cm}^{-1}$ and 32 repetitious scans were averaged for each spectrum. The sample contact area was circular with a diameter of approximately $1.5 \mathrm{~mm}$ as the samples were pressed against the diamond crystal of the ATR device. Spectra were baseline corrected and area normalized manually using Opus software (Opus Software Limited, Grantham, UK). Averages of 43A, 41A and 1A spectra were used to represent apoplast lines, while representative spectra for endoplasmic reticulum and vacuole targeted lines were computed by averaging data from lines 28ER and 24ER and $61 \mathrm{~V}, 15 \mathrm{~V}$ and $2 \mathrm{~V}$, respectively. Spectra were subject to PCA and digital subtraction data analysis (XLSTAT 2013.4 statistical software; Addinsoft, New York, NY, USA).

\section{Cell wall analysis}

For each line, 50 to 60 whole plants were pooled and ground as described above. Ground samples (60 to $70 \mathrm{mg}$ ) were used to prepare alcohol insoluble residue (AIR) as described previously [33]. Briefly, ground material was sequentially extracted over a sintered glass funnel under vacuum with two volumes of $100 \mathrm{ml}$ of ice cold $80 \%$ ethanol, $100 \%$ ethanol, chloroform:methanol (1:1) and 100\% acetone. Starch was removed by treatment with Type II-A Bacillus $\alpha$-amylase (Sigma-Aldrich; approximately 1,000 units/100 mg cell wall AIR) in $50 \mathrm{mM}$ sodium phosphate buffer (pH 7.0) at $25^{\circ} \mathrm{C}$ in a shaking incubator for $48 \mathrm{~h}$. De-starched samples were centrifuged $(3,660 \times g$ for $10 \mathrm{~min}$ at $25^{\circ} \mathrm{C}$ ) and the pellet was subsequently washed thrice with deionized water and recovered by centrifugation $\left(3,660 \times g\right.$ for $10 \mathrm{~min}$ at $\left.25^{\circ} \mathrm{C}\right)$. The resulting pellets were suspended in $500 \mu \mathrm{l}$ of acetone and evaporated with a stream of air at $36^{\circ} \mathrm{C}$ until dry. For total sugar analysis, triplicate AIR samples $(5 \mathrm{mg})$ of each line $(43 \mathrm{~A}, 41 \mathrm{~A}, 1 \mathrm{~A}$,
28ER, 24ER, $61 \mathrm{~V}, 15 \mathrm{~V}, 2 \mathrm{~V}$ and $\mathrm{C}$ ) were hydrolyzed with $72 \% \mathrm{H}_{2} \mathrm{SO}_{4}$ and the released sugars were quantitated by a combination gas chromatography-mass spectroscopy (GC-MS) of alditol acetate derivatives. The remains after trifluoroacetic acid (TFA) treatment were hydrolyzed in Updegraff reagent (acetic acid:nitric acid:water, 8:1:2 v/v) and used in an anthrone assay to quantify crystalline cellulose [51]. Uronic acid content in triplicate AIR samples of each representative line (43A, 41A, 1A, 28ER, 24ER, $61 \mathrm{~V}$, $15 \mathrm{~V}, 2 \mathrm{~V}$ and $\mathrm{C}$ ) were quantified by adapting the microassay of van den Hoogen et al. [52] and using galacturonic acid as a standard. An average of 43A, 41A and 1A, 28ER and 24ER and $61 \mathrm{~V}, 15 \mathrm{~V}$ and $2 \mathrm{~V}$ were used to represent apoplast lines (A), endoplasmic reticulum (ER) and vacuole (V) targeted lines, respectively.

To determine lignin content [53], approximately $1 \mathrm{mg}$ of AIR samples (three replicates for each line, that is, 43A, 41A, 1A, 28ER, 24ER, $61 \mathrm{~V}, 15 \mathrm{~V}, 2 \mathrm{~V}$ and C) were solubilized in freshly prepared acetyl bromide solution $(100 \mu \mathrm{l}$ of $25 \%(\mathrm{v} / \mathrm{v})$ acetyl bromide in glacial acetic acid) for $3 \mathrm{~h}$ at $50^{\circ} \mathrm{C}$, with $2 \mathrm{M}$ sodium hydroxide $(400 \mu \mathrm{l})$ and $0.5 \mathrm{M}$ hydroxylamine hydrochloride $(70 \mu \mathrm{l})$ being added to stop the reaction. Absorbance at $280 \mathrm{~nm}$ was measured using Synergy HT multi-detection microplate reader (Biotek Instruments, Inc., Winooski, VT, USA). Cell wall phenolics were extracted according to Buanafina et al. [14] with minor modifications. Briefly, following the extraction of chlorophyll pigments with aqueous methanol, ester bound compounds were extracted from ground plant material (50 $\mathrm{mg}$, three repeats) with $1 \mathrm{M}$ $\mathrm{NaOH}(5 \mathrm{ml})$ followed by incubation at $25^{\circ} \mathrm{C}$ for $24 \mathrm{~h}$ in the dark. Aliquots of the mixture were combined with a 1.2 volume of $100 \mathrm{mM} \mathrm{HCl}$ and centrifuged $(1,000 \times g$, $20 \mathrm{~min})$. The supernatant was diluted with four volumes of methanol and UV spectrum was recorded between 200 to $400 \mathrm{~nm}$.

\section{Enzyme saccharification assay}

Alkaline peroxide pretreatment was performed as described by Banerjee et al. [54]. Briefly, $50 \mathrm{ml}$ of $1 \% \mathrm{H}_{2} \mathrm{O}_{2}$ was adjusted to $\mathrm{pH} 11.5$ with $5 \mathrm{M} \mathrm{NaOH}$ and mixed with $1 \mathrm{~g}$ of ground AIR plant material (as prepared above) in a $250 \mathrm{ml}$ Erlenmeyer flask. Final concentrations were $1 \% \mathrm{H}_{2} \mathrm{O}_{2}(300 \mathrm{mM}), 0.8 \% \mathrm{NaOH}(200 \mathrm{mM})$ and $2 \%$ biomass. The flasks were incubated at $24^{\circ} \mathrm{C}$ with shaking at $90 \mathrm{rpm}$ for $24 \mathrm{~h}$. The slurries were neutralized to $\mathrm{pH} 7$ by the addition of $12 \mathrm{~N} \mathrm{HCl}$. Residual $\mathrm{H}_{2} \mathrm{O}_{2}$ was inactivated by addition of $59 \mu \mathrm{l}$ of catalase $(28 \mathrm{mg}$ protein/ml; Sigma-Aldrich). After inactivation of catalase by heating at $90^{\circ} \mathrm{C}$ for $15 \mathrm{~min}$, the flask contents were centrifuged and dried at $55^{\circ} \mathrm{C}$. Alkaline peroxide treated material from transgenic lines 43A, 41A, 1A, 28ER, 24ER, $61 \mathrm{~V}, 15 \mathrm{~V}, 2 \mathrm{~V}$ and control were suspended at a final concentration of $0.5 \%(\mathrm{w} / \mathrm{v})$ in $50 \mathrm{mM}$ sodium citrate 
buffer (pH 5.0) containing $5 \mu \mathrm{g} / \mathrm{ml}$ tetracycline, $5 \mu \mathrm{g} / \mathrm{ml}$ cycloheximide and $0.02 \%$ sodium azide. The slurry was kept in suspension using a paddle reservoir designed for dispensing pharmaceutical beads on the Biomek FXP (model VP 756C-1P100; V\&P Scientific, Inc., San Diego, CA, USA). A total of $200 \mu \mathrm{l}$ of substrate slurry was then dispensed into mini-Eppendorf tubes, followed by addition of commercial enzymes (Accellerase 1500) at a final concentration of $15 \mathrm{mg}$ protein per $\mathrm{g}$ of cellulose and the mixture was incubated at $50^{\circ} \mathrm{C}$ for $48 \mathrm{~h}$. The tubes were centrifuged at $1,500 \times g$ for $5 \mathrm{~min}$ to separate solid residue from hydrolyzed biomass. The supernatants $(100 \mu \mathrm{l})$ were transferred into a Costar 96-well plate and heated at $100^{\circ} \mathrm{C}$ for $10 \mathrm{~min}$ to inactivate the enzymes. Each reaction mixture was run in duplicate, sampled twice, and the supernatants were assayed twice for released glucose using a K-GLUC kit (Megazyme, Bray, Ireland). Sugar assays were conducted in 96-well plates using $194 \mu \mathrm{l}$ of assay reagent and $12 \mu \mathrm{l}$ of sample. The plates were incubated at $50^{\circ} \mathrm{C}$ for 20 min before reading absorbance at $510 \mathrm{~nm}$ using the Synergy HT multidetection microplate reader (Biotek Instruments, Inc.).

\section{Additional files}

Additional file 1: Summary of alfalfa transformation experiments $(\mathrm{n}=3)$.

Additional file 2: Southern blot analysis of faeB-apoplast line 10 A2. The gDNA was cut with BamHI and the blot was probed with DIG-labeled faeB gene fragments (651 bp). Lane 1, 1 kb DNA ladder $(1 \mu \mathrm{g})$; lane 2, wild type alfalfa gDNA $(20 \mu \mathrm{g})$; lane 3, 10 A2 gDNA $(20 \mu \mathrm{g})$; and lane 4, faeB-apoplast plasmid DNA (5 $\mathrm{ng}$ ).

Additional file 3: Concentration of VFA (mM) after (A) $6 \mathrm{~h}$ and (B) $72 \mathrm{~h}$ of in vitro incubation of control and transgenic lines in mixed rumen fluid. Bars indicate standard error. VFA, volatile fatty acid.

Additional file 4: Ammonia production during in vitro digestion of control and transgenic lines in mixed ruminal fluid. Bars indicate standard error. *Differs to control at $P<0.05$.

Additional file 5: Correlation matrix table and correlation circle of axis $\mathrm{F} 1$ and $\mathrm{F} 3$.

Additional file 6: Difference between digestion of control and transgenic cell walls as evident from digital subtraction of FTIR spectra of respective digesta residue after $72 \mathrm{~h}$ of incubation with rumen fluid. (A) Average spectrum of $24 \mathrm{ER}$ and $28 \mathrm{ER}$; and (B) average spectrum of $43 \mathrm{~A}, 41 \mathrm{~A}$ and $1 \mathrm{~A}$ versus wild type control. A, apoplast; ER, endoplasmic reticulum; FTIR, Fourier transformed infrared spectroscopy.

Additional file 7: FTIR spectral differences between control and transgenic cell walls after $6 \mathrm{~h}$ and $72 \mathrm{~h}$ of incubation with rumen fluid as an indicator of the progressive digestion of the plant cell wall. (A) Wild type control; (B) average spectrum of 24ER and 28ER; and (C) average spectrum of $43 \mathrm{~A}, 41 \mathrm{~A}$ and $1 \mathrm{~A}$. A, apoplast; ER, endoplasmic reticulum; FTIR, Fourier transformed infrared spectroscopy.

Additional file 8: Total sugar and uronic acid content of cell walls. (A) TFA and sulfuric acid solubilized total sugar content as determined by anthrone method. (B) Uronic acid content of TFA and sulfuric acid solubilized cell wall fractions. Bars indicate standard error of mean $(n=3)$. *Differs to control at $P<0.05$. Apoplast (A), faeB-apoplast (average of 43A, $41 \mathrm{~A}$ and $1 \mathrm{~A}$ ); endoplasmic reticulum (ER), faeB-ER (average of 24ER and 28ER); and vacuole (V), faeB-vacuole (average of $61 \mathrm{~V}, 15 \mathrm{~V}$ and $2 \mathrm{~V}$ ). A, apoplast; ER, endoplasmic reticulum; TFA, trifluoroacetic acid; V, vacuole; WT, wild type control.

Additional file 9: Schematic maps of vector sequence for apoplast, chloroplast, endoplasmic reticulum and vacuole targeted feruloyl esterase. c-Myc, cMyc tag mouse antibody sequence from GenScript; CTPP, vacuole retention signal; ER, endoplasmic reticulum; KDEL, endoplasmic reticulum retention signal; PIN, potato protease inhibitor II terminator sequence; PR1b, secretory signal peptide from tobacco; Strepll, Strepll purification tag WSHPQFEK; tCUP4, enhanced tCUP4 promoter sequence.

Additional file 10: Sequences of synthetic faeB genes.

Additional file 11: Schematic map of the 5,103 bp pEACH vector based on pPZP100 [36]. Modifications described in the Methods section. Par A, par A MYB recognition sequences.

Additional file 12: Schematic map of the pEACH 7,205 construct showing restriction enzyme sites and insert size.

Additional file 13: Alfalfa tissue culture and transformation with Agrobacterium tumefaciens LBA4404. (A) Callus formation on selection medium plates after culture with Agrobacterium containing faeB gene targeted four different cellular compartments (apoplast, chloroplast, vacuole and endoplasmic reticulum), 4 weeks. (B) Embryo formed on callus, 5 weeks. (C, D) Embryo formation, 7 weeks. (E, F) Embryo germination on selection medium, 9 to 10 weeks. (G) Transgenic alfalfa plants transferred to magenta box, 12 weeks. $(\mathrm{H})$ Transgenic alfalfa plant transferred to soil, 18 weeks. (I) Potted transgenic alfalfa plants in a growth chamber, 28 weeks.

\section{Abbreviations}

A: Apoplast; AHP: Alkaline hydrogen peroxide; AIR: Alcohol insoluble residue; ATR: Attenuated total reflectance; C: Control; CAZyme: Carbohydrate-active enzyme; CCAC: Canadian Council on Animal Care;

CMC: Carboxymethylcellulose; DIG: Digoxigenin;

EDTA: Ethylenediaminetetraacetic acid; ER: Endoplasmic reticulum;

FAEA: Type A ferulic acid esterase; faeA: Feruloyl esterase A gene; FAEB: Type B ferulic acid esterase; faeB: Feruloyl esterase B gene; FTIR: Fourier transformed infrared spectroscopy; GC-MS: Gas chromatography-mass spectrometry; GUS: $\beta$-glucuronidase; IgG: Immunoglobulin G; IVDMD: In vitro dry matter disappearance; MOPS: 3-(N-morpholino)propanesulfonic acid; MSO: Murashige and Skoog medium; NPTII: Neomycin phosphotransferase II; OD: Optical density; PBS: Phosphate-buffered saline; PCA: Principal component analysis; PCR: Polymerase chain reaction; PIN: Potato proteinase inhibitor; PMSF: Phenylmethanesulfonyl fluoride; pNPG: $p$-Nitrophenyl- $\beta-D-$ glucopyranoside; PVPP: Polyvinylpolypyrrolidone; Rubisco: Ribulose-1,5bisphosphate carboxylase/oxygenase; TCA: Trichloroacetic acid; T-DNA: Transfer DNA; TFA: Trifluoroacetic acid; V: Vacuole; VFA: Volatile fatty acid.

\section{Competing interests}

The authors declare that they have no competing interests.

\section{Authors' contributions}

$D C W B, T M, A T, A B$ and $B M$ conceived and designed the experiment. $A B, L J$, $S Y H, K K, C J A$ and MLG performed the experiments. AB, $L, S Y H, K K, C J A, M L G$, DCWB, TM and YW interpreted the data. AB, YW, TM, DCWB, AT, BM, LJ, SYH, KK, CJA and MLG drafted and revised the work. All authors read and approved the final manuscript.

\section{Acknowledgments}

The authors are grateful to Genencor (Danisco US Inc., Genencor Division, Rochester, NY, USA) for generously providing samples of Accellerase 1500 and Accellerase XC. The authors also thank Dr Yu Lei of the Tsang laboratory at McGill University (Montreal, QC, Canada) for the qualitative screening of transgenic lines for esterase activity. This work was supported by the Cellulosic Biofuel Network of Agriculture and Agri-Food Canada, Genome Alberta and the Genozymes project of Genome Quebec. This is LRC contribution number 38713010. 


\section{Author details}

${ }^{1}$ Agriculture and Agri-Food Canada, Lethbridge Research Centre, 5403 1st Avenue South, Lethbridge, AB T1J 4B1, Canada. ${ }^{2}$ Agriculture and Agri-Food Canada, Southern Crop Protection and Food Research Centre, London, ON N5V 4T3, Canada. ${ }^{3}$ Canadian Centre for Agri-Food Research in Health and Medicine, St Boniface Hospital Research Centre, Winnipeg, MB R2H 2A6, Canada. ${ }^{4}$ Biology Department, Concordia University, Montreal, QC H4B 1R6, Canada.

Received: 10 November 2013 Accepted: 21 February 2014

Published: 20 March 2014

\section{References}

1. Uffen RL: Xylan degradation: a glimpse at microbial diversity. J Ind Microbiol Biotechnol 1997, 19:1-6.

2. Calviño M, Bruggmann R, Messing J: Screen of genes linked to high-sugar content in stems by comparative genomics. Rice 2008, 1:166-176.

3. Hatfield RD, Ralph J: Modelling the feasibility of intramolecular dehydrodiferulate formation in grass walls. J Sci Food Agric 1999, 79:425-427

4. Himmel ME, Ding SY, Johnsonl DK, Adney WS, Nimlos MR, Brady JW, Foust TD: Biomass recalcitrance: engineering plants and enzymes for biofuels production. Science 2007, 315:804-807.

5. Kumar R, Mago G, Balan V, Wyman CE: Physical and chemical characterizations of corn Stover and poplar solids resulting from leading pretreatment technologies. Bioresour Technol 2009, 100:3948-3962.

6. Taherzadeh MJ, Karimi K: Pretreatment of lignocellulosics waste to improve ethanol and biogas production: a review. Internat J Mole Sci 2008, 9:1621-1651.

7. Abramson M, Shoseyov O, Shani Z: Plant cell wall reconstruction toward improved lignocellulosics production and processability. Plant Sci 2010, 178:61-72.

8. Boerjan W: Biotechnology and the domestication of forest trees. Curr Opin Biotechnol 2005, 16:159-166.

9. Taylor LE, Dai Z, Decker SR, Brunecky R, Adney WS, Ding SY, Himmel ME: Heterologous expression of glycosyl hydrolases in planta: a new departure for biofuels. Trends Biotechnol 2008, 26:413-424.

10. Mellerowicz EJ, Sundberg B: Wood cell walls: biosynthesis, developmental dynamics and their implications for wood properties. Curr Opin Plant Biol 2008, 11:293-300.

11. Roach MJ, Mokshina NY, Badhan A, Snegireva AV, Hobson N, Deyholos MK, Gorshkova TA: Development of cellulosic secondary walls in flax fibers requires $\beta$-galactosidase. Plant Physiol 2011, 156:1351-1363.

12. Stewart JJ, Akiyama T, Chapple C, Ralph J, Mansfield SD: The effects on lignin structure of overexpression of ferulate 5-hydroxylase in hybrid poplar. Plant Physiol 2009, 150:621-635.

13. Buanafina MMO, Langdon T, Hauck B, Dalton SJ, Morris P: Manipulating the phenolic acid content and digestibility of Italian ryegrass (Lolium multiflorum) by vacuolar-targeted expression of a fungal ferulic acid esterase. Appl Biochem Biotechnol 2006, 129-132:416-426.

14. Buanafina MMO, Langdon T, Hauck B, Dalton S, Morris P: Expression of a fungal ferulic acid esterase increases cell wall digestibility of tall fescue (Festuca arundinacea). Plant Biotechnol J 2008, 6:264-280

15. Tsai AY, Canam T, Gorzsás A, Mellerowicz EJ, Campbell MM, Master ER: Constitutive expression of a fungal glucuronoyl esterase in Arabidopsis reveals altered cell wall composition and structure. Plant Biotechnol J 2012, 11:1-11.

16. Chen F, Dixon RA: Lignin modification improves fermentable sugar yields for biofuel production. Nat Biotechnol 2007, 25:759-761.

17. Ramírez L, Arrizon J, Sandoval G, Cardador A, Bello-Mendoza R, Lappe P, Mateos-Díaz JC: A new microplate screening method for the simultaneous activity quantification of feruloyl esterases, tannases, and chlorogenate esterases. Appl Biochem Biotechnol 2008, 151:711-723.

18. Sauer M, Paciorek T, Benková E, Friml J: Immunocytochemical techniques for whole-mount in situ protein localization in plants. Nat Protoc 2006, 1:98-103.

19. Gierlinger N, Schwanninger M: Chemical imaging of poplar wood cell walls by confocal raman microscopy. Plant Physiol 2006, 140:1246-1254.

20. Marković JP, Štrbanović RT, Terzić DV, Djokić D, Simić AS, Vrvić MM, Živković SP: Changes in lignin structure with maturation of alfalfa leaf and stem in relation to ruminants nutrition. Afr J Agric Res 2012, 7:257-264.
21. Li M, Foster C, Kelkar S, Pu Y, Holmes D, Ragauskas A, Saffron MC, Hodge DB: Structural characterization of alkaline hydrogen peroxide pretreated grasses exhibiting diverse lignin phenotypes. Biotechnol Biofuels 2012, 5:38.

22. Titgemeyer EC, Bourquin LD, Fahey GC: Disappearance of cell wall monomeric components from fractions chemically isolated from alfalfa leaves and stems following in-situ ruminal digestion. J Sci Food Agric 1992, 58:451-463.

23. Giraldo LA, Tejido ML, Ranilla MJ, Ramos S, Carro MD: Influence of directfed fibrolytic enzymes on diet digestibility and ruminal activity in sheep fed a grass hay-based diet. J Anim Sci 2008, 86:1617-1623.

24. Nsereko VL, Smiley BK, Rutherford WM, Spielbauer A, Forrester KJ, Hettinger GH, Harman EK, Harman BR: Influence of inoculating forage with lactic acid bacterial strains that produce ferulate esterase on ensilage and ruminal degradation of fiber. Anim Feed Sci Technol 2008, 145:122-135.

25. Wang Y, Spratling BM, ZoBell DR, Wiedmeier RD, McAllister TA: Effect of alkali pretreatment of wheat straw on the efficacy of exogenous fibrolytic enzymes. J Anim Sci 2004, 82:198-208.

26. Menassa R, Kennette W, Nguyen V, Rymerson R, Jevnikar A, Brandle J: Subcellular targeting of human interleukin-10 in plants. J Biotechnol 2004, 108:179-183.

27. Orr JD, Edwards R, Dixon RA: Stress responses in alfalfa (Medicago sativa L.) (XIV. Changes in the levels of phenylpropanoid pathway intermediates in relation to regulation of $\mathrm{L}$-phenylalanine ammonia-lyase in elicitor-treated cell-suspension cultures). Plant Physiol 1993, 101:847-856.

28. Williamson G, Vallejo J: Chemical and thermal stability of ferulic acid esterase from Aspergillus niger. Int J Biol Macromol 1997, 21:163-167.

29. Williamson G, Kroon PA, Faulds CB: Hairy plant polysaccharides: a close shave with microbial esterases. Microbiol 1998, 144:2011-2023.

30. Donohoe BS, Decker SR, Tucker MP, Himmel ME, Vinzant TB: Visualizing lignin coalescence and migration through maize cell walls following thermochemical pretreatment. Biotechnol Bioeng 2008, 101:913-925.

31. Jing $X$, Zhang $X$, Bao J: Inhibition performance of lignocellulose degradation products on industrial cellulase enzymes during cellulose hydrolysis. Appl Biochem Biotechnol 2009, 159:693-707.

32. Rahikainen J, Mikander S, Marjamaa K, Tamminen T, Lappas A, Viikari L, Kruus K: Inhibition of enzymatic hydrolysis by residual lignins from softwood: study of enzyme binding and inactivation on lignin-rich surface. Biotechnol Bioeng 2011, 108:2823-2834.

33. Li M, Xiong G, Li R, Cui J, Tang D, Zhang B, Pauly M, Cheng Z, Zhou Y: Rice cellulose synthase-like D4 is essential for normal cell-wall biosynthesis and plant growth. Plant J 2009, 60:1055-1069.

34. Cutt JR, Dixon DC, Carr JP, Klessig DF: Isolation and nucleotide sequence of CDNA clones for the pathogenesis-related proteins PR1a, PR1b and PRIc of Nicotiana tabacum cv. Xanthi nc induced by TMV infection. Nucl Acids Res 1988, 16:9861-9865.

35. Gomord V, Denmat L-A, Fitchette-Lainé A-C, Satiat-Jeunemaitre B, Hawes C, Faye $L$ : The $C$-terminal HDEL sequence is sufficient for retention of secretory proteins in the endoplasmic reticulum (ER) but promotes vacuolar targeting of proteins that escape the ER. Plant J 1997, 11:313-325.

36. Hajdukiewicz P, Svab Z, Maliga P: The small, versatile PPZP family of Agrobacterium binary vectors for plant transformation. Plant Mol Biol 1994, 25:989-994.

37. Yanofsky RL, Fine M, Pellow JW: A mutant neomycin phosphotransferease II gene reduces the resistance of transformants to antibiotic selection pressures. Proc Natl Acad Sci USA 1990, 87:3435-3439.

38. Urao T, Yamaguchi-Shinozaki K, Urao S, Shinazaki K: An Arabidopsis myb homolog is induced by dehydration stress and its gene products binds to the conserved MYB recognition sequence. Plant Cell 1993, 5:1529-1539.

39. Zupan J, Muth TR, Draper O, Zambryski P: The transfer of DNA from Agrobacterium tumefaciens into plants: a feast of fundamental insights. Plant J 2000, 23:11-28.

40. Gudynaite-Savitch L, Johnson DA, Miki B: Strategies to mitigate transgenepromoter interactions. Plant Biotechnol J 2009, 7:472-485.

41. Joensuu JJ, Conley AJ, Lienemann M, Brandle JE, Linder MB, Menassa R: Hydrophobin fusions for high-level transient protein expression and purification in Nicotiana benthamiana. Plant Physiol 2010, 152:622-633.

42. Murashige T, Skoog F: A revised medium for rapid growth and bioassays with tobacco tissue cultures. Plant Physiol 1962, 15:473-497.

43. Han S, Kowalczys K, Latoszek-Green M, Brown DCW: Agrobacterium-mediated genetic transformation of alfalfa through somatic embryogenesis. In Somatic Embryogenesis and Genetic Transformation in Plants. Edited by 
Julian A, Srivastava PS, Sharma MP. New Delhi: Narosa Publishing House; 2013:219-250

44. Tian LN, Brown DCW, Watson E: Continuous long-term somatic embryogenesis in alfalfa. In Vitro Cell Dev Biol Plant 2002, 38:279-284.

45. Atanassov A, Brown DCW: Plant regeneration from suspension culture and mesophyll protoplasts of Medicago sativa L. Plant Cell Tissue Organ Cult 1984, 3:149-162.

46. Bingham ET, Hurley LV, Kaatz DM, Saunders JW: Breeding alfalfa which regenerates from callus tissue in culture. Crop Sci 1975, 15:719-721.

47. Menk KH, Raab L, Salewski A, Steingass H, Fritz D, Scneider W: The estimation of digestibility and metabolisable energy content of ruminant feedstuffs from the gas production when they are incubated with rumen liquor in vitro. J Agric Sci 1979, 93:217-222.

48. Wang $Y, X u Z$, Bach SJ, McAllister TA: Effect of phlorotannins from Ascophyllum nodosum (brown seaweed) on in vitro ruminal digestion of mixed forage or barley grain. Anim Feed Sci Technol 2008, 145:375-395.

49. Weatherburn MW: Phenol-hypochlorite reaction for determination of ammonia. Anal Chem 1967, 39:971-874.

50. Wang Y, McAllister TA, Newbold CJ, Rode LM, Cheeke PR, Cheng KJ: Effect of Yucca schidigera extract on fermentation and degradation of steroidal saponins in the rumen simulation technique (RUSITEC). Anim Feed Sci Technol 1998, 74:143-153.

51. Updegraff DM: Semimicro determination of cellulose in biological materials. Anal Biochem 1969, 32:420-424.

52. van den Hoogen BM, van Weeren PR, Lopes-Cardozo M, van Golde LM, Barneveld A, van de Lest CH: A microtiter plate assay for the determination of uronic acids. Anal Biochem 1998, 257:107-111.

53. Fukushima RS, Hatfield RD: Extraction and isolation of lignin for utilization as a standard to determine lignin concentration using the acetyl bromide spectrophotometric method. J Agri and Food Chem 2001, 49:3133-3139

54. Banerjee G, Car S, Scott-Craig JS, Borrusch MS, Walton JD: Rapid optimization of enzyme mixtures for deconstruction of diverse pretreatment/biomass feedstock combinations. Biotechnol Biofuels 2010, $3: 22$.

doi:10.1186/1754-6834-7-39

Cite this article as: Badhan et al.: Expression of a fungal ferulic acid esterase in alfalfa modifies cell wall digestibility. Biotechnology for Biofuels 2014 7:39.

\section{Submit your next manuscript to BioMed Central and take full advantage of:}

- Convenient online submission

- Thorough peer review

- No space constraints or color figure charges

- Immediate publication on acceptance

- Inclusion in PubMed, CAS, Scopus and Google Scholar

- Research which is freely available for redistribution 